Supporting Information

\title{
Importance of $\pi$-interactions involving chelate rings in addition to the tetrel bonds in crystal engineering: $A$ combined experimental and theoretical study on a series of hemi- and holo-directed nickel(II)/lead(II) complexes
}

Saikat Mirdyaa, Sourav Roy ${ }^{a}$, Sudipta Chatterjee, ${ }^{\text {b }}$ Antonio Bauzác, Antonio Frontera*,c, Shouvik Chattopadhyay*a ${ }^{a}$ Department of Chemistry, Inorganic Section, Jadavpur University, Kolkata - 700032, India Tel: +9133-2457-2941; E-mail: shouvik.chem@gmail.com ${ }^{b}$ Department of Chemistry, Serampore College, Serampore, Hooghly-712201, India ${ }^{c}$ Department of Chemistry, Universitat de les Illes Balears, Crta de Valldemossa km 7.5, 07122 Palma de Mallorca (Baleares), SPAIN

Experimental section

Materials

All chemicals were of reagent grade and used as purchased from Sigma-Aldrich without further purification.

Preparation of the ligand, 2,2'-[(2,2-dimethyl-1,3-propanediyl)bis(iminomethylene)]bis[6methoxy-phenol] $\left(H_{2} L^{1}\right)$

A Schiff base ligand $\left(\mathrm{H}_{2} \mathrm{~L}^{\prime}\right)$ was synthesized by refluxing 2,2-dimethyl-1,3propanediamine $(0.1 \mathrm{~mL}, 1 \mathrm{mmol})$ and 3-methoxysalicylaldehyde (305 $\mathrm{mg}, 2 \mathrm{mmol})$ in methanol 
solution $(10 \mathrm{~mL})$ for ca. $2 \mathrm{~h}$. The Schiff base ligand was not purified but used directly for the preparation of the reduced Schiff base ligand $\left(\mathrm{H}_{2} \mathrm{~L}^{1}\right)$. Afterwards, the methanol solution $(10 \mathrm{~mL})$ was cooled to $0^{\circ} \mathrm{C}$ and solid sodium borohydride ( $4 \mathrm{mmol}, 151 \mathrm{mg}$ ) was added to it with constant stirring. Then the resulting solution was acidified with glacial acetic acid $(2 \mathrm{~mL})$ and stirred for 10 minutes. The solution was evaporated to dryness under reduced pressure in a rotary evaporator $\left(\sim 60^{\circ} \mathrm{C}\right)$. The residue was then dissolved in water $(15 \mathrm{~mL})$ and extracted with dichloromethane $(15 \mathrm{~mL})$. The organic part was dried over anhydrous sodium acetate and the solvent (i.e. dichloromethane) was evaporated under reduced pressure using a rotary evaporator to get the reduced Schiff base ligand $\left(\mathrm{H}_{2} \mathrm{~L}^{1}\right)$.

Preparation of the ligand, 2,2'-[(2,2-dimethyl-1,3-propanediyl)bis(iminomethylene)]bis[6ethoxy-phenol] $\left(H_{2} L^{2}\right)$

It was prepared in a similar manner as that of $\mathrm{H}_{2} \mathrm{~L}^{1}$ only 3-ethoxysalicylaldehyde (332 $\mathrm{mg}, 2 \mathrm{mmol}$ ) was used instead of 3-methoxysalicylaldehyde.

\section{Preparation of $\left[(S C N) N_{i L}{ }^{1}\left(\mu_{1,3}-N C S\right) P b\right](1)$}

A methanol solution $(5 \mathrm{~mL})$ of nickel(II) thiocyanate tetrahydrate $(250 \mathrm{mg}, 1 \mathrm{mmol})$ was added to the methanol solution $(10 \mathrm{~mL})$ of the reduced Schiff base ligand $\mathrm{H}_{2} \mathrm{~L}^{1}$, with constant stirring. A methanol (5 mL) solution of lead(II) nitrate (331 mg, 1 mol) was then added to it and the stirring was continued for about $1 \mathrm{~h}$. The resulting mixture was then refluxed for ca. $2 \mathrm{~h}$. Single crystals, suitable for X-ray diffraction, were obtained after 4-5 days upon slow evaporation of the solution in an open atmosphere. 
Yield: $527 \mathrm{mg}$ ( 70\%) based on nickel(II). Anal. Calc. for $\mathrm{C}_{23} \mathrm{H}_{28} \mathrm{~N}_{4} \mathrm{NiO}_{4} \mathrm{PbS}_{2}$ (FW: 754.50):

C, 36.71; H, 3.48; N, 7.45; Found: C, 36.6; H, 3.3; N, 7.5\%. FT-IR $\left(\mathrm{KBr}, \mathrm{cm}^{-1}\right): 3264\left(\mathrm{v}_{\mathrm{N}-\mathrm{H}}\right) ; 2963-$ $2839\left(v_{C-H}\right) ; 2074\left(v_{N C S}\right) \cdot \lambda_{\max }(\mathrm{nm})\left[\varepsilon_{\max }\left(\right.\right.$ lit mol $\left.\left.\mathrm{m}^{-1} \mathrm{~cm}^{-1}\right)\right]$ (acetonitrile): $251\left(1.11 \times 10^{3}\right) ; 286(5.9 \mathrm{X}$ $\left.10^{2}\right) ; 603(25.2)$

\section{Preparation of $\left[(S C N) N i L^{1}(\mu-O A C) P b\right](2)$}

Complex $\mathbf{2}$ was prepared in a similar method to that of complex 1, except that the lead(II) acetate trihydrate (379 mg, $1 \mathrm{mmol}$ ) was added instead of lead(II) nitrate. Single crystals, suitable for X-ray diffraction, were obtained after 4-5 days upon slow evaporation of the solution in an open atmosphere.

Yield: $512 \mathrm{mg}$ ( 68\%) based on nickel(II). Anal. Calc. for $\mathrm{C}_{24} \mathrm{H}_{31} \mathrm{~N}_{3} \mathrm{NiO}_{6} \mathrm{PbS}$ (FW: 755.47):

C, 38.26; H, 3.88; N, 5.58. Found: C, 38.1; H, 3.7; N, 5.7\%, FT-IR $\left(\mathrm{KBr}, \mathrm{cm}^{-1}\right): 3286\left(\mathrm{~V}_{\mathrm{N}-\mathrm{H}}\right) ; 2970-$ $2818\left(v_{\mathrm{C}-H}\right) ; 2087\left(v_{\mathrm{NCS}}\right), 1250,1226\left(\mathrm{v}_{\mathrm{COO}}\right) \cdot \lambda_{\max }(\mathrm{nm})\left[\varepsilon_{\max }\left(\mathrm{lit} \mathrm{mol}^{-1} \mathrm{~cm}^{-1}\right)\right]$ (acetonitrile): 237 $\left(1.93 \times 10^{3}\right) ; 286\left(1.59 \times 10^{2}\right) ; 608(33.9)$.

\section{Preparation of $\left[(\mathrm{SCN}) \mathrm{NiL}^{2}(\mu-\mathrm{OAC}) \mathrm{Pb}\right](3)$}

Complex $\mathbf{3}$ was prepared in a similar method to that of complex 2, except that $\mathrm{H}_{2} \mathrm{~L}^{2}$ was used instead of $\mathrm{H}_{2} \mathrm{~L}^{1}$. Single crystals, suitable for X-ray diffraction, were obtained after 4-5 days upon slow evaporation of the solution in an open atmosphere.

Yield: $540 \mathrm{mg}$ ( 69\%) based on nickel(II). Anal. Calc. for $\mathrm{C}_{26} \mathrm{H}_{35} \mathrm{~N}_{3} \mathrm{NiO}_{6} \mathrm{PbS}$ (FW: 783.52): C, 39.96; H, 4.26; N, 5.38; Found: C, 39.8; H, 4.2; N, 5.5\%. FT-IR $\left(\mathrm{KBr}, \mathrm{cm}^{-1}\right): 3211\left(\mathrm{v}_{\mathrm{N}-\mathrm{H}}\right) ; 2922-$ 
$2842\left(v_{\mathrm{C}-\mathrm{H}}\right) ; 2088\left(\mathrm{v}_{\mathrm{NCS}}\right), 1250,1229\left(\mathrm{v}_{\mathrm{COO}}{ }^{-}\right) . \lambda_{\max }(\mathrm{nm})\left[\varepsilon_{\max }\left(\right.\right.$ lit $\left.\left.\mathrm{mol}^{-1} \mathrm{~cm}^{-1}\right)\right]$ (acetonitrile): 243 $\left(2.32 \times 10^{3}\right) ; 286\left(1.59 \times 10^{2}\right) ; 602(31.20)$.

Preparation of $\left[\left\{(\mathrm{DMSO})\left(\mathrm{H}_{2} \mathrm{O}\right) \mathrm{NiL}^{1}\right\}_{2} \mathrm{~Pb}\right]\left(\mathrm{ClO}_{4}\right)_{2}(4)$

A methanol solution ( $5 \mathrm{~mL}$ ) of the nickel(II) perchlorate hexahydrate ( $\sim 31 \mathrm{mg}, 2 \mathrm{mmol}$ ) was added to the methanol solution $(10 \mathrm{~mL})$ of the reduced Schiff base ligand $\mathrm{H}_{2} \mathrm{~L}^{1}$ with constant stirring followed by the addition of methanolic solution $(5 \mathrm{~mL})$ of lead(II) perchlorate monohydrate ( $\sim 225 \mathrm{mg}, 1 \mathrm{mmol})$. The stirring was continued for $30 \mathrm{~min}$. After that, the reaction mixture was refluxed for ca. $2 \mathrm{~h}$ and allowed to cool. A few drops of DMSO were then added to it. The resulting reaction mixture was left unperturbed for slow evaporation at room temperature. After few days, blue crystals, suitable for X-Ray diffraction were collected by filtration.

Yield: $970 \mathrm{mg}$ ( $\sim 66 \%$ ) based on nickel(II). Anal. Calc. for $\mathrm{C}_{46} \mathrm{H}_{72} \mathrm{Cl}_{2} \mathrm{~N}_{4} \mathrm{Ni}_{2} \mathrm{O}_{20} \mathrm{PbS}_{2}$ (FW: 1460.68): C, 39.62; H, 5.40; N, 3.75; Found: C, 40.1; H, 5.2; N, 3.9\%. FT-IR $\left(\mathrm{KBr}, \mathrm{cm}^{-1}\right): 3506$ $\left(v_{\mathrm{O}-H}\right), 3272\left(v_{\mathrm{N}-\mathrm{H}}\right) ; \quad 2937-2875\left(\mathrm{v}_{\mathrm{C}-\mathrm{H}}\right) ; 1085-1063\left(\mathrm{v}_{\mathrm{ClO}}{ }^{-}\right) . \lambda_{\max }(\mathrm{nm})\left[\varepsilon_{\max }\left(\mathrm{lit} \mathrm{mol}^{-1} \mathrm{~cm}^{-1}\right)\right]$ (acetonitrile): $242\left(3.03 \times 10^{3}\right) ; 285\left(1.87 \times 10^{2}\right) ; 600(23.16)$.

\section{Preparation of $\left[\left\{(\mathrm{DMSO})\left(\mathrm{H}_{2} \mathrm{O}\right) \mathrm{NiL}^{2}\right\}_{2} \mathrm{~Pb}\right]\left(\mathrm{ClO}_{4}\right)_{2} \cdot 4 \mathrm{DMSO}(5)$}

Complex $\mathbf{5}$ was prepared in a similar method to that of complex 4, except that $\mathrm{H}_{2} \mathrm{~L}^{2}$ was used instead of $\mathrm{H}_{2} \mathrm{~L}^{1}$. Single crystals, suitable for X-ray diffraction, were obtained after 4-5 days upon slow evaporation of the solution in an open atmosphere. 
Yield: $1010 \mathrm{mg}$ ( $\sim 55 \%)$ based on nickel(II). Anal. Calc. for $\mathrm{C}_{58} \mathrm{H}_{104} \mathrm{Cl}_{2} \mathrm{~N}_{4} \mathrm{Ni}_{2} \mathrm{O}_{24} \mathrm{PbS}_{6}$ (FW: 1829.29): C, 43.82; H, 5.58; N, 4.46; Found: C, 43.0; H, 4.8; N, 5.2\%. FT-IR $\left(\mathrm{KBr}, \mathrm{cm}^{-1}\right): 3305$ $\left(v_{\mathrm{O}-H}\right), 3008\left(\mathrm{v}_{\mathrm{N}-\mathrm{H}}\right) ; 2940-2873\left(\mathrm{v}_{\mathrm{C}-\mathrm{H}}\right) ; 1084-1011\left(\mathrm{v}_{\mathrm{ClO}}{ }^{-}\right) . \lambda_{\max }(\mathrm{nm})\left[\varepsilon_{\max }\left(l_{\mathrm{lit}} \mathrm{mol}^{-1} \mathrm{~cm}^{-1}\right)\right]$ (acetonitrile): $252\left(1.26 \times 10^{3}\right) ; 288\left(1.64 \times 10^{2}\right) ; 600(18.48)$.

\section{Physical measurements}

Elemental analyses (carbon, hydrogen and nitrogen) were performed using a PerkinElmer $240 \mathrm{C}$ elemental analyzer. IR spectra in $\mathrm{KBr}\left(4500-500 \mathrm{~cm}^{-1}\right)$ were recorded with a PerkinElmer Spectrum Two spectrophotometer. Electronic spectra in acetonitrile were recorded on a JASCO V-630 spectrophotometer. The powder XRD data were collected on a Bruker D8 Advance $\mathrm{X}$-ray diffractometer using $\mathrm{Cu} \mathrm{K}_{\alpha}$ radiation $(\lambda=1.548 \AA$ ) generated at $40 \mathrm{kV}$ and $40 \mathrm{~mA}$. The PXRD spectra were recorded in a $2 \theta$ range of $5-50^{\circ}$ using 1-D Lynxeye detector at ambient conditions.

\section{X-ray Crystallography}

Suitable single crystals of complexes 1-5 were used for data collection using a 'Bruker D8 QUEST area detector' diffractometer equipped with graphite-monochromated Mo $K_{\alpha}$ radiation $(\lambda=0.71073 \AA$ A). The molecular structures were solved by direct method and refined by fullmatrix least squares on $F^{2}$ using the SHELX-18 package. ${ }^{1}$ Non-hydrogen atoms were refined with anisotropic thermal parameters. The hydrogen atoms attached to nitrogen atoms were located by difference Fourier maps and were kept at fixed positions. All other hydrogen atoms were placed in their geometrically idealized positions and constrained to ride on their parent atoms. 
Multi-scan empirical absorption corrections were applied to the data using the program SADABS. ${ }^{2}$

\section{Hirshfeld surfaces}

Hirshfeld surfaces ${ }^{3,4}$ of complexes 1-5 were determined using Crystal Explorer. ${ }^{5}$ 2D fingerprint plots of the Hirshfeld surfaces were also shown as plots of $d_{i}$ against $d_{e}$.

\section{Theoretical methods}

The geometries of the complexes included in this study were computed at the PBEOD3/def2-TZVP level of theory using the crystallographic coordinates. For the calculations TURBOMOLE 7.0 program ${ }^{6}$ has been used. The Grimme's dispersion ${ }^{7}$ correction has also been used since it is adequate for the evaluation of non-covalent interactions. The basis set superposition error for the calculation of interaction energies has been corrected using the counterpoise method. ${ }^{8}$ The $\mathrm{NCl}$ plot ${ }^{9}$ iso-surfaces have been used to characterize non-covalent interactions. They correspond to both favourable and unfavourable interactions, as differentiated by the sign of the second density Hessian eigenvalue and defined by the isosurface colour. The colour scheme is a red-yellow-green-blue scale with red for $\rho^{+}$cut (repulsive) and blue for $\rho_{\text {cut }}^{-}$(attractive). Yellow and green isosurfaces correspond to weak repulsive and weak attractive interactions, respectively. ${ }^{10}$ The Gaussian-0911 PBE-D/def2-TZVP level of theory wave function has been used to generate the $\mathrm{NCl}$ plot. The molecular electrostatic potential (MEP) surfaces have been computed using the Gaussian-09 program at the same level and using the 0.001 a.u. isosurface as a good estimation of the van der Waals surface and the surfaces have been visualized using the GaussView program. ${ }^{11}$ 


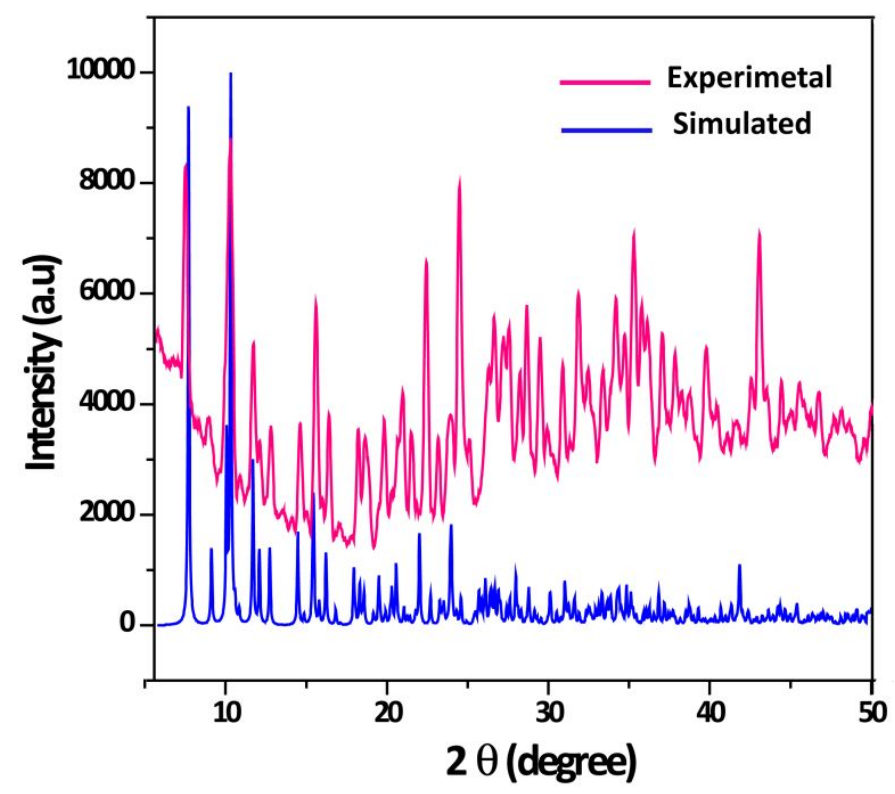

Fig. S1. Experimental and simulated PXRD patterns of complex 2 confirming purity of the bulk material.

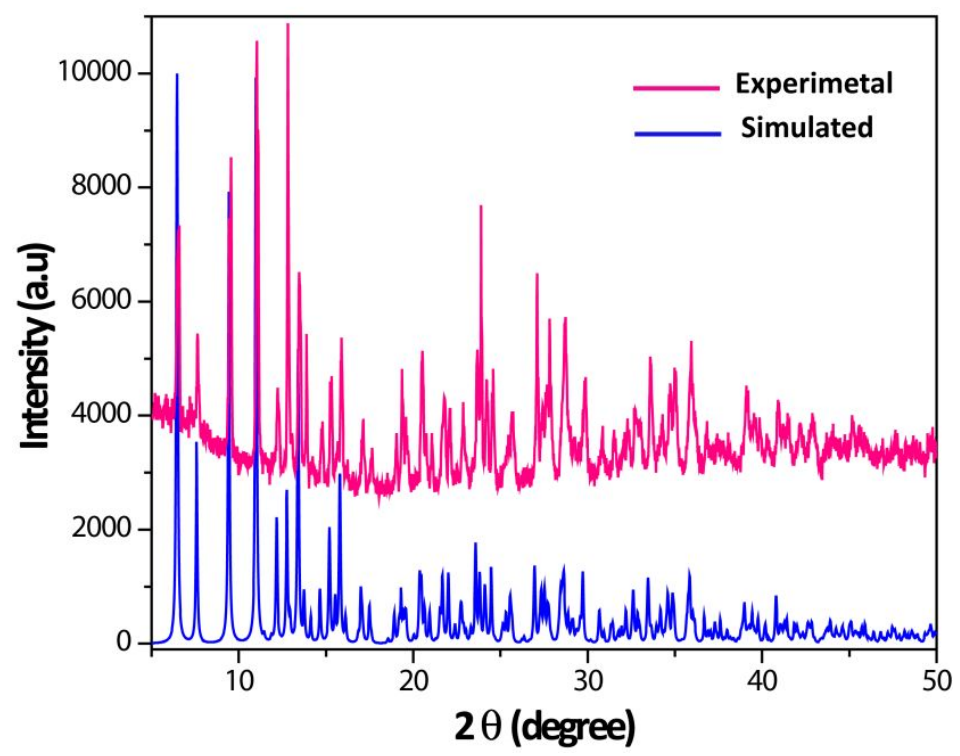

Fig. S2. Experimental and simulated PXRD patterns of complex $\mathbf{3}$ confirming purity of the bulk material. 


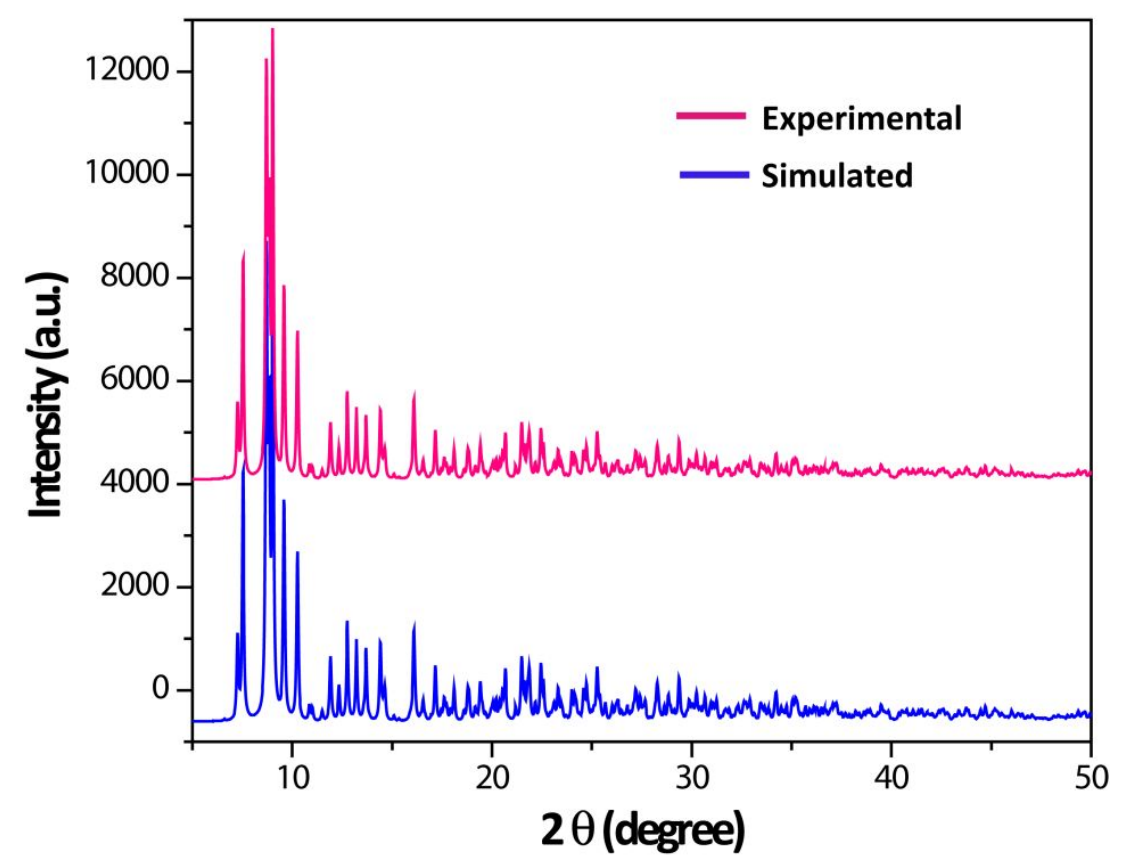

Fig. S3. Experimental and simulated PXRD patterns of complex $\mathbf{4}$ confirming purity of the bulk material.

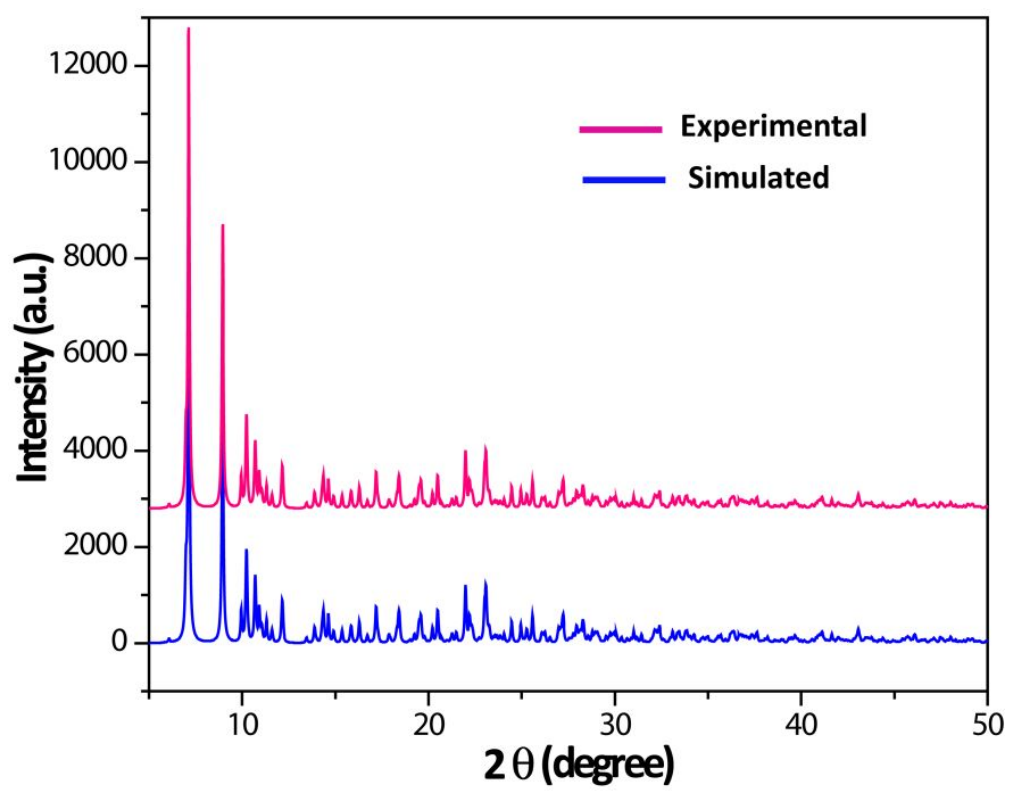

Fig. S4. Experimental and simulated PXRD patterns of complex $\mathbf{5}$ confirming purity of the bulk material. 


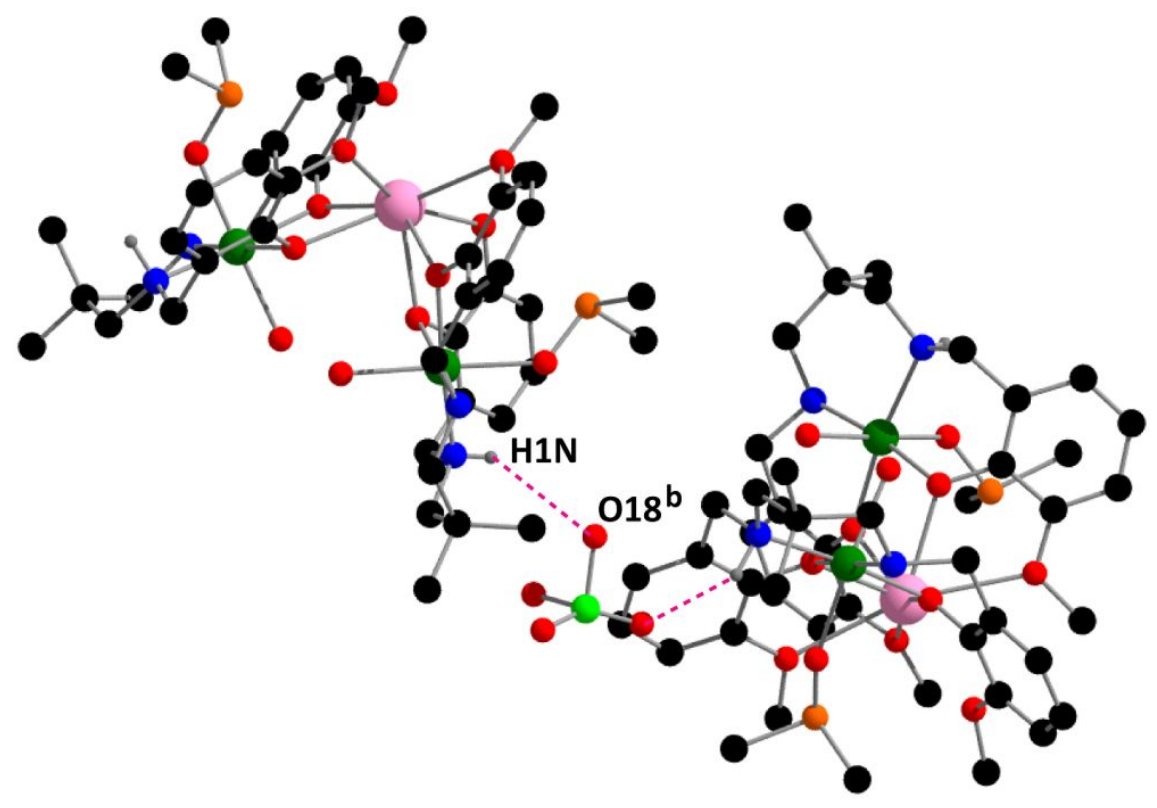

Fig. S5. 1D chain formed by the weak $\mathrm{H}$-bonding interaction in complex 4. Only the relevant atoms have been shown for clarity. Symmetry transformation, $b=-1+x, y, z$ )

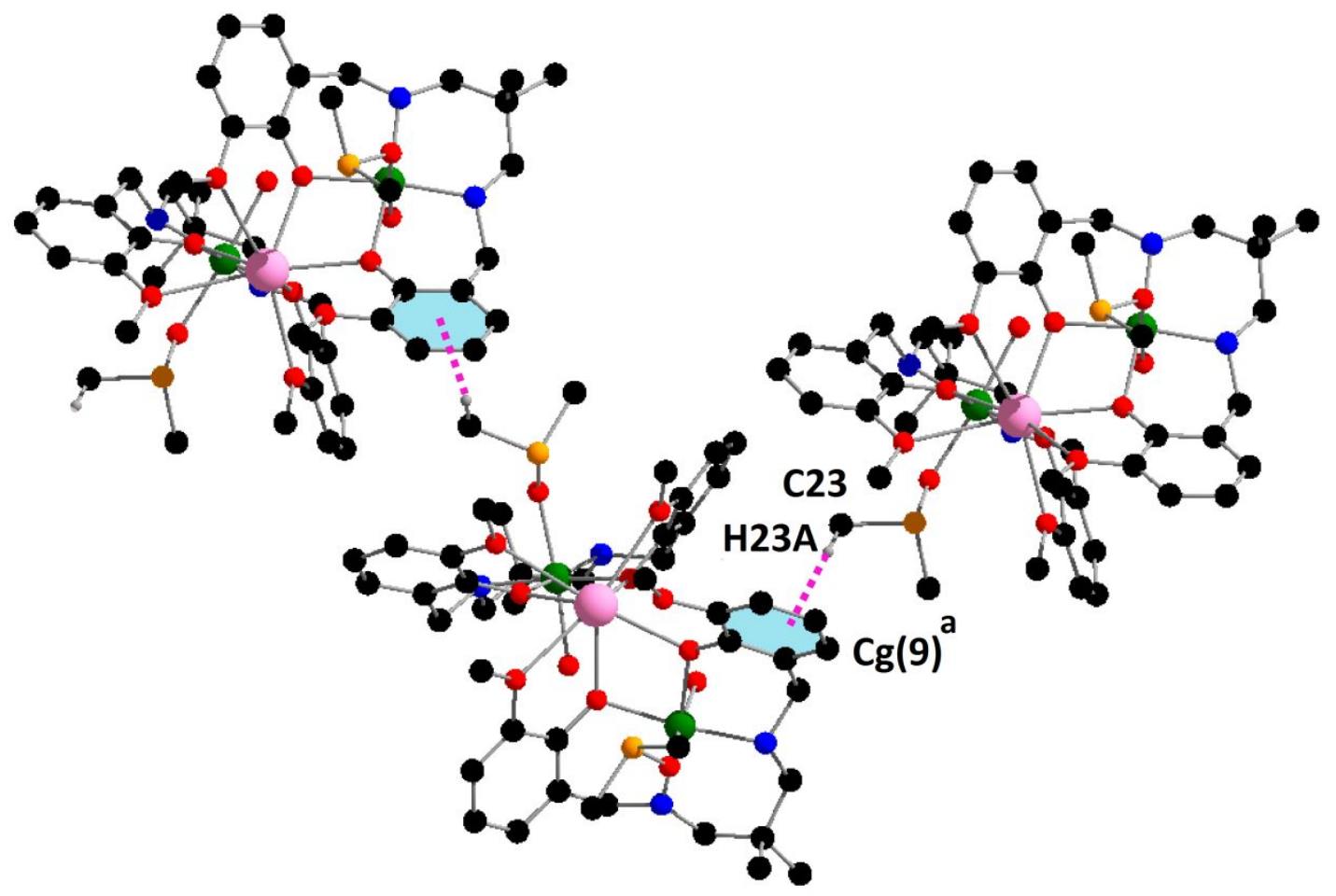


Fig. S6. Intermolecular $\mathrm{C}-\mathrm{H} \cdots \pi$ interaction of complex 4. Only relevant atoms have been shown for clarity. Symmetry transformation; ${ }^{a}=x, 1 / 2-y, 1 / 2+z$.

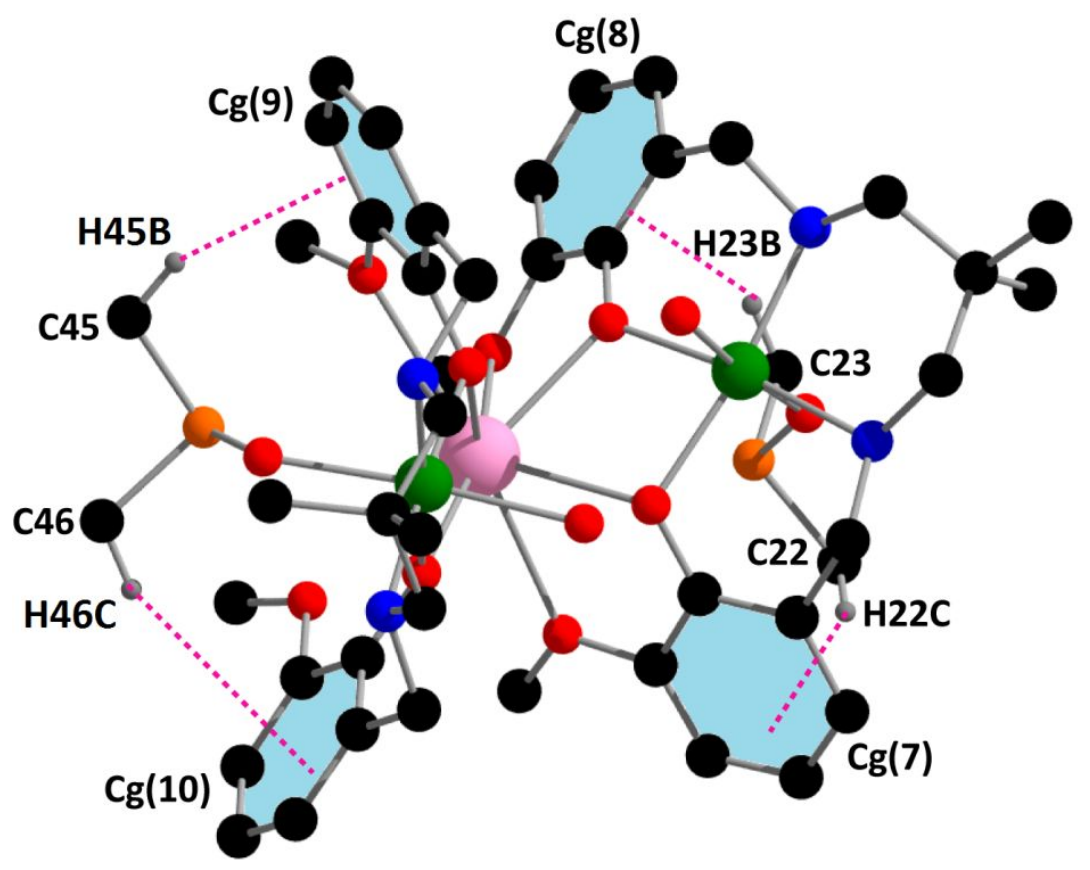

Fig. S7. Intra-molecular $\mathrm{C}-\mathrm{H} \cdots \pi$ interactions observed in complex 4. Only relevant atoms have been shown for clarity. 


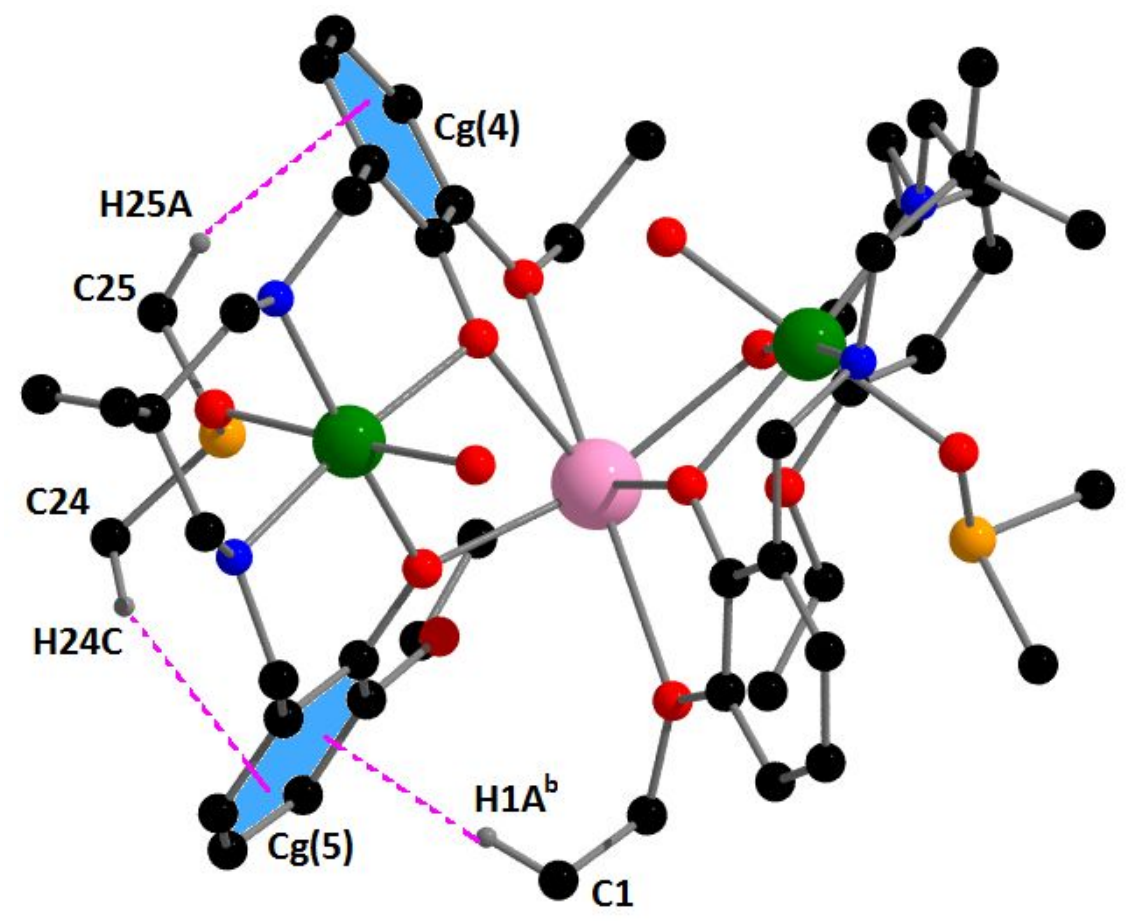

Fig. S8. $\mathrm{C}-\mathrm{H} \cdots \pi$ interactions observed in complex $\mathbf{5}$. Only the relevant atoms have been shown for clarity. Symmetry transformation $(\mathrm{b}=1 / 2-x, y, 1-z)$.

\section{Hirshfeld surfaces}

The Hirshfeld surface emerged from an attempt to define the space occupied by a molecule in a crystal for the purpose of subdividing the crystal electron density into molecular fragments. ${ }^{12} d_{\text {norm }}$ is a normalised contact distance. ${ }^{13}$ Intermolecular contacts are highlighted in the $d_{\text {norm }}$ surface (when atoms make intermolecular contacts closer than the sum of their van der Waals radii, these contacts will be highlighted in red whereas longer contacts are blue, and contacts around the sum of van der Waals radii are white). Hirshfeld surfaces of complexes 1-5 have been mapped over $d_{\text {norm }}$ (range of -0.1 to $1.5 \AA$ ) [Fig. S9]. Red spots on these surfaces denote the dominant interactions $[\mathrm{N} \cdots \mathrm{H} / \mathrm{H} \cdots \mathrm{N}, \mathrm{S} \cdots \mathrm{H} / \mathrm{H} \cdots \mathrm{S}$ and $\mathrm{O} \cdots \mathrm{H} / \mathrm{H} \cdots \mathrm{O}]$. As the Hirshfeld 
surface defines the shape of the molecule in terms of its surrounding crystalline environment, the local shape of the surface may provide some chemical insight whereas shape index is a qualitative measure of shape and can be sensitive to very subtle changes in surface shape, particularly in regions where the total curvature (or the curvedness) is very low. ${ }^{14}$

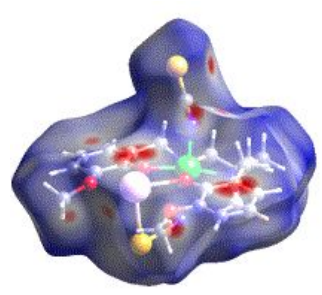

1

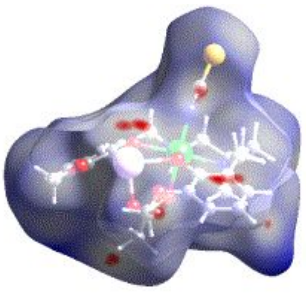

2

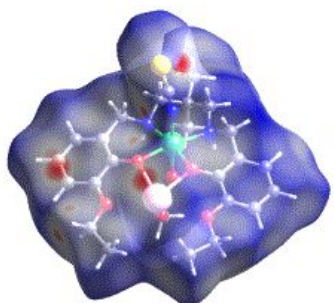

3

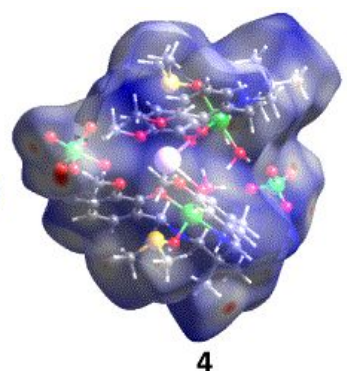

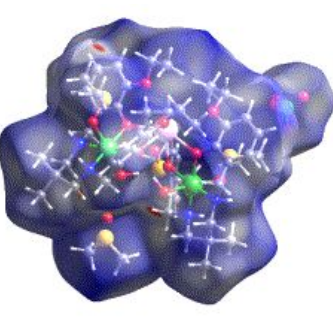

5

Fig. S9. Hirshfeld surfaces $\left(d_{\text {norm }}\right)$ of complexes 1-5.

The $2 \mathrm{D}$ fingerprint plots, ${ }^{15}$ which are used to analyze the intermolecular contacts at the same time, revealed that the main intermolecular interactions in the complexes are $\mathrm{S} \cdots \mathrm{H} / \mathrm{H} \cdots \mathrm{S}$, $\mathrm{N} \cdots \mathrm{H} / \mathrm{H} \cdots \mathrm{N}$ and $\mathrm{O} \cdots \mathrm{H} / \mathrm{H} \cdots \mathrm{O}$. Fig. S10 represents the $2 \mathrm{D}$ plots of complexes 1,2 and $\mathbf{3}$. The $\mathrm{O} \cdots \mathrm{H}$ 

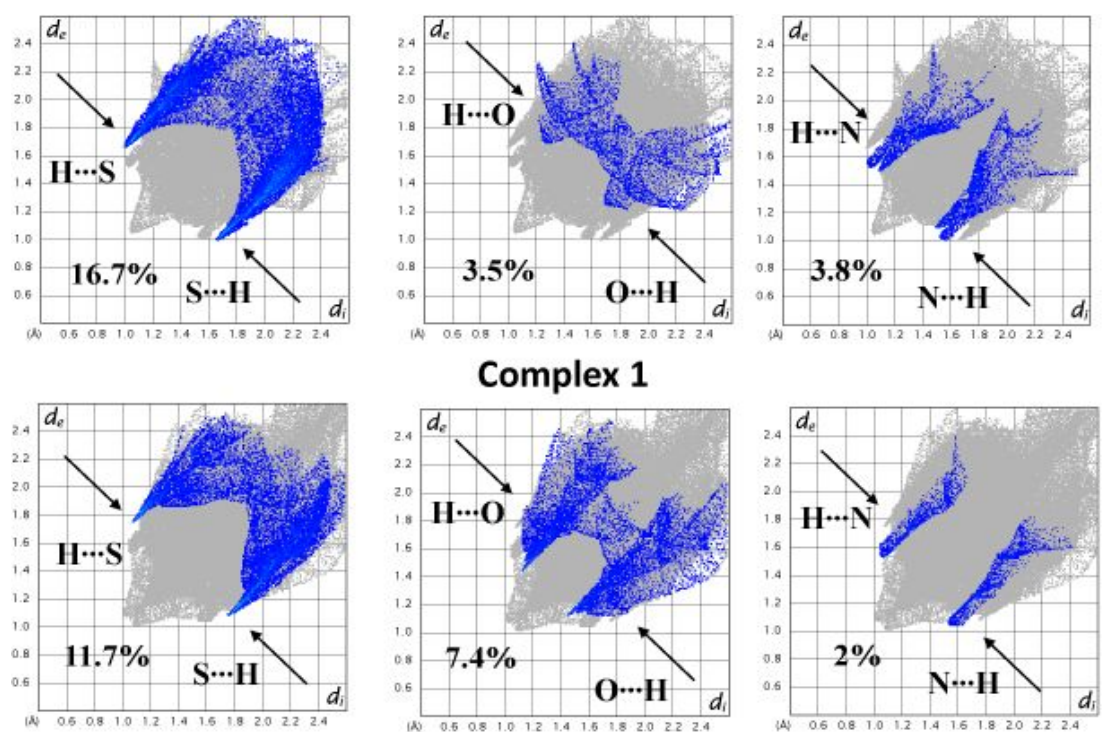

Complex 1
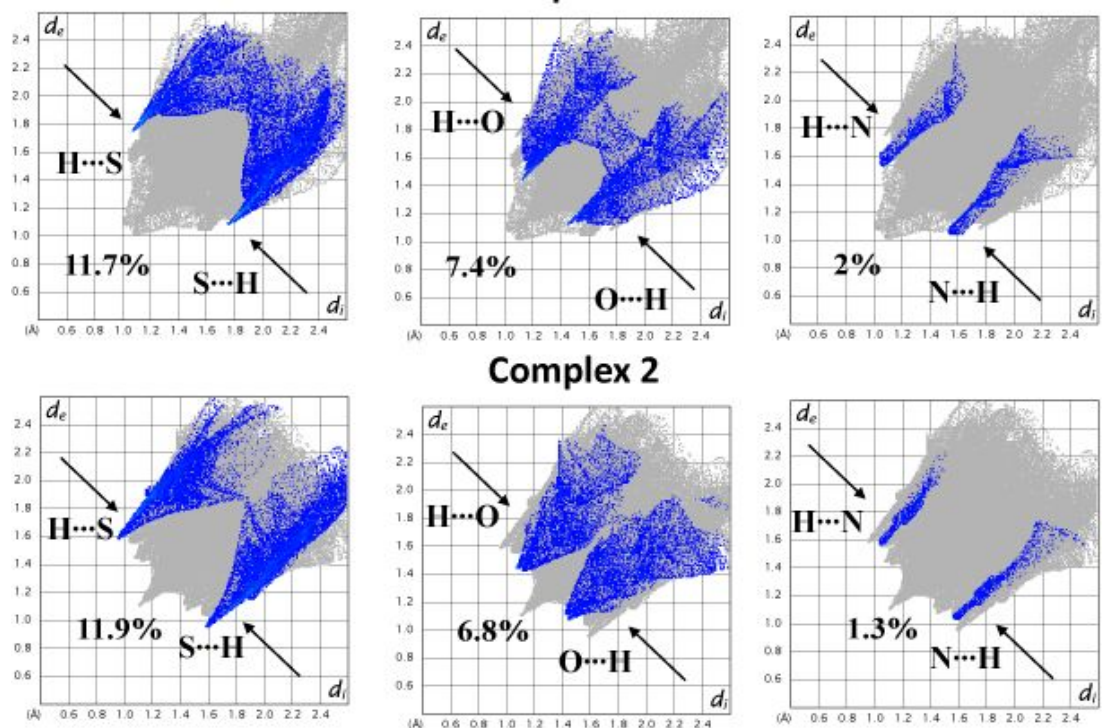

Complex 2
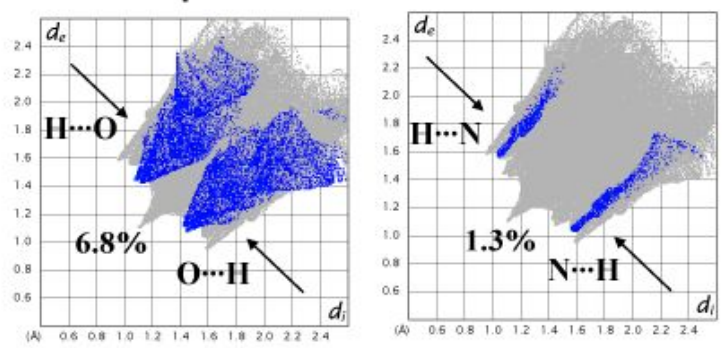

Complex 3

Fig. S10. Fingerprint plots of complexes 1, 2 and 3.

interactions are higher in complexes $\mathbf{2}$ and $\mathbf{3}$ compared to complex $\mathbf{1}$ due to the presence of acetate group which is absent in complex 1 . Complex 1 contains an extra thiocyanate which results in more $\mathrm{S} \cdots \mathrm{H}(16.7 \%)$ interaction compared to the other ones. Complexes 4 and 5 contains perchlorate ions in the lattice moieties which result in hydrogen bonding interactions. The $\mathrm{O} \cdots \mathrm{H}$ interactions in the $2 \mathrm{D}$ plot (Fig. S11) also validate these results.

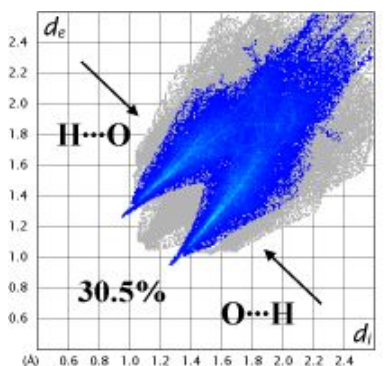

4

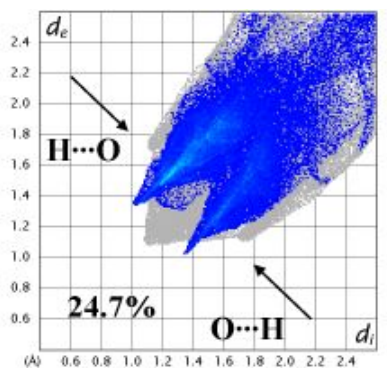

5 
Fig. S11. Fingerprint plot resolved into $\mathrm{H} \cdots \mathrm{O} / \mathrm{O} \cdots \mathrm{H}$ contacts contributed to the total Hirshfeld Surface area of complexes 4 and 5.

Interesting $\mathrm{Pb} \cdots \mathrm{S}$ and $\mathrm{S} \cdots \mathrm{S}$ contacts (Fig. S12) are observed in complexes $\mathbf{1}$ and $\mathbf{2}$. These contacts are not present in isostructural complex 3. It is due to the steric crowding of ethoxy group [compared to methoxy group (for complexes $\mathbf{1}$ and 2)] which averts the sulphur atom of a thiocyanate to come in closer contact with the lead(II) center prevent such contacts. These contacts may lead to the formation of different unconventional supramolecular interactions which is quite fascinating. To investigate these, theoretical calculations have been done and the interaction energies have been calculated.

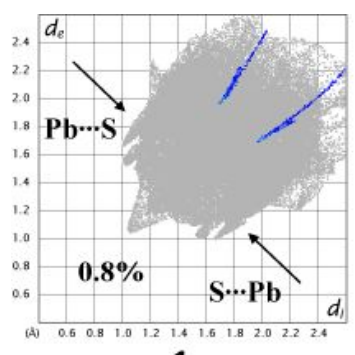

1
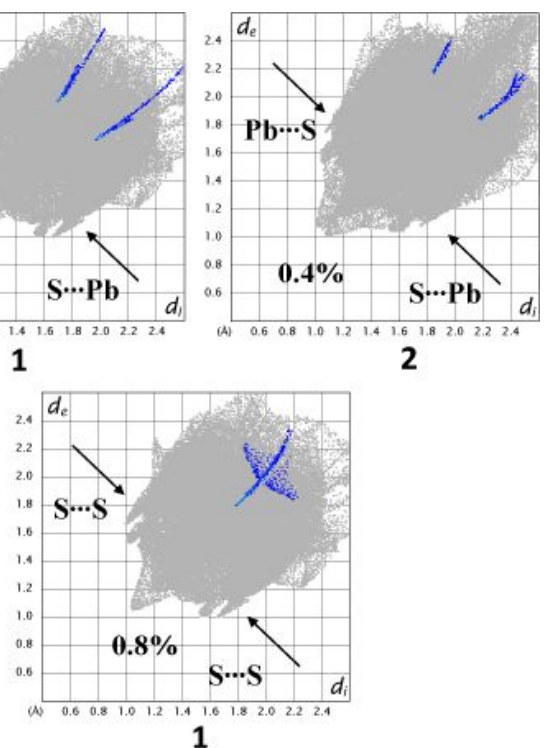

Fig. S12. Fingerprint plot resolved into $\mathrm{Pb} \cdots \mathrm{S} / \mathrm{S} \cdots \mathrm{Pb}$ and $\mathrm{S} \cdots \mathrm{S} / \mathrm{S} \cdots \mathrm{S}$ contacts contributed to the total Hirshfeld Surface area of complexes $\mathbf{1}$ and $\mathbf{2}$.

Table S1. Selected bond angles ( ${ }^{\circ}$ ) of complexes 1-5.

Complex

$\mathrm{O}(1)-\mathrm{Pb}(1)-\mathrm{O}(2)$
1

$68.7(2)$
2

74.3(3)
3

73.73(8)
4

$67.29(11)$
5

67.86(12) 


\begin{tabular}{|c|c|c|c|c|c|}
\hline $\mathrm{O}(1)-\mathrm{Pb}(1)-\mathrm{O}(3)$ & $63.3(2)$ & $65.0(3)$ & $64.63(8)$ & $62.83(12)$ & $60.32(14)$ \\
\hline $\mathrm{O}(1)-\mathrm{Pb}(1)-\mathrm{O}(4)$ & 131.72(19) & $138.1(3)$ & 138.66(8) & 111.39(11) & $108.00(13)$ \\
\hline $\mathrm{O}(1)-\mathrm{Pb}(1)-\mathrm{O}(6)$ & - & $81.3(3)$ & $87.24(9)$ & - & - \\
\hline $\mathrm{O}(2)-\mathrm{Pb}(1)-\mathrm{O}(3)$ & $131.6(2)$ & $136.5(3)$ & $138.09(8)$ & $106.03(13)$ & $106.71(14)$ \\
\hline $\mathrm{O}(2)-\mathrm{Pb}(1)-\mathrm{O}(4)$ & $64.44(19)$ & $66.7(3)$ & $65.91(8)$ & $59.53(11)$ & $58.84(13)$ \\
\hline $\mathrm{O}(2)-\mathrm{Pb}(1)-\mathrm{O}(6)$ & - & $84.3(3)$ & $84.46(9)$ & - & - \\
\hline $\mathrm{O}(3)-\mathrm{Pb}(1)-\mathrm{O}(4)$ & 157.15(19) & $142.6(3)$ & $152.96(9)$ & $93.30(14)$ & $92.31(15)$ \\
\hline $\mathrm{O}(3)-\mathrm{Pb}(1)-\mathrm{O}(6)$ & - & $75.3(3)$ & $88.94(9)$ & - & - \\
\hline $\mathrm{O}(4)-\mathrm{Pb}(1)-\mathrm{O}(6)$ & - & $80.2(3)$ & $80.52(9)$ & - & - \\
\hline $\mathrm{S}(2)-\mathrm{Pb}(1)-\mathrm{O}(1)$ & $88.91(15)$ & - & - & - & - \\
\hline $\mathrm{S}(2)-\mathrm{Pb}(1)-\mathrm{O}(2)$ & $89.17(16)$ & - & - & - & - \\
\hline $\mathrm{S}(2)-\mathrm{Pb}(1)-\mathrm{O}(3)$ & 83.99(17) & - & - & - & - \\
\hline $\mathrm{S}(2)-\mathrm{Pb}(1)-\mathrm{O}(4)$ & $79.75(15)$ & - & - & - & - \\
\hline $\mathrm{O}(1)-\mathrm{Ni}(1)-\mathrm{O}(2)$ & $80.4(2)$ & $83.2(3)$ & $82.19(9)$ & $81.88(13)$ & $81.81(15)$ \\
\hline $\mathrm{O}(1)-\mathrm{Ni}(1)-\mathrm{O}(5)$ & - & $87.8(3)$ & $88.54(10)$ & $85.93(14)$ & $85.12(17)$ \\
\hline $\mathrm{O}(1)-\mathrm{Ni}(1)-\mathrm{N}(1)$ & $92.4(3)$ & $91.8(3)$ & $90.88(10)$ & 91.97(17) & $92.97(18)$ \\
\hline $\mathrm{O}(1)-\mathrm{Ni}(1)-\mathrm{N}(2)$ & $167.9(3)$ & $173.3(3)$ & $170.90(11)$ & $172.02(15)$ & $173.7(2)$ \\
\hline $\mathrm{O}(1)-\mathrm{Ni}(1)-\mathrm{N}(3)$ & $93.4(3)$ & $92.2(3)$ & $93.27(12)$ & - & - \\
\hline $\mathrm{O}(2)-\mathrm{Ni}(1)-\mathrm{O}(5)$ & - & $89.2(3)$ & $87.80(10)$ & $87.40(15)$ & $90.25(15)$ \\
\hline $\mathrm{O}(2)-\mathrm{Ni}(1)-\mathrm{N}(1)$ & $168.1(3)$ & $172.4(3)$ & $171.51(10)$ & $171.74(17)$ & 173.04(19) \\
\hline $\mathrm{O}(2)-\mathrm{Ni}(1)-\mathrm{N}(2)$ & $89.6(3)$ & $91.1(3)$ & 89.66(10) & $91.57(15)$ & $92.4(2)$ \\
\hline $\mathrm{O}(2)-\mathrm{Ni}(1)-\mathrm{N}(3)$ & $96.6(3)$ & $95.6(4)$ & $93.58(12)$ & - & - \\
\hline $\mathrm{O}(2)-\mathrm{Ni}(1)-\mathrm{N}(4)$ & $87.3(3)$ & - & - & - & - \\
\hline$N(1)-N i(1)-N(2)$ & $96.3(3)$ & $93.5(4)$ & $96.88(11)$ & $94.98(19)$ & $93.00(2)$ \\
\hline$N(1)-N i(1)-N(3)$ & $93.2(3)$ & $90.3(4)$ & $91.68(13)$ & - & - \\
\hline$N(2)-N i(1)-N(3)$ & $94.5(3)$ & $92.0(4)$ & $91.24(13)$ & - & - \\
\hline $\mathrm{O}(1)-\mathrm{Ni}(1)-\mathrm{N}(4)$ & $84.4(3)$ & - & - & - & - \\
\hline $\mathrm{N}(1)-\mathrm{Ni}(1)-\mathrm{N}(4)$ & $82.6(3)$ & - & - & - & - \\
\hline
\end{tabular}




\begin{tabular}{|c|c|c|c|c|c|}
\hline$N(2)-N i(1)-N(4)$ & $88.3(3)$ & - & - & - & - \\
\hline$N(3)-N i(1)-N(4)$ & $175.2(3)$ & - & - & - & - \\
\hline $\mathrm{O}(5)-\mathrm{Ni}(1)-\mathrm{N}(1)$ & - & $84.9(4)$ & $87.14(11)$ & $97.71(18)$ & $93.91(18)$ \\
\hline $\mathrm{O}(5)-\mathrm{Ni}(1)-\mathrm{N}(2)$ & - & $88.6(4)$ & $87.12(11)$ & $89.24(17)$ & $92.4(2)$ \\
\hline $\mathrm{O}(5)-\mathrm{Ni}(1)-\mathrm{N}(3)$ & - & $175.2(5)$ & $177.85(12)$ & - & - \\
\hline $\mathrm{O}(1)-\mathrm{Ni}(1)-\mathrm{O}(6)$ & - & - & - & $98.66(14)$ & $95.53(17)$ \\
\hline $\mathrm{O}(2)-\mathrm{Ni}(1)-\mathrm{O}(6)$ & - & - & - & $92.18(15)$ & $93.32(15)$ \\
\hline $\mathrm{O}(5)-\mathrm{Ni}(1)-\mathrm{O}(6)$ & - & - & - & $175.29(15)$ & $176.42(15)$ \\
\hline $\mathrm{O}(6)-\mathrm{Ni}(1)-\mathrm{N}(1)$ & - & - & - & $83.26(18)$ & $82.55(18)$ \\
\hline $\mathrm{O}(6)-\mathrm{Ni}(1)-\mathrm{N}(2)$ & - & - & - & $86.09(17)$ & $87.3(2)$ \\
\hline $\mathrm{O}(1)-\mathrm{Pb}(1)-\mathrm{O}(7)$ & - & - & - & $82.67(10)$ & - \\
\hline $\mathrm{O}(1)-\mathrm{Pb}(1)-\mathrm{O}(8)$ & - & - & - & $83.15(10)$ & - \\
\hline $\mathrm{O}(1)-\mathrm{Pb}(1)-\mathrm{O}(9)$ & - & - & - & $124.57(12)$ & - \\
\hline $\mathrm{O}(1)-\mathrm{Pb}(1)-\mathrm{O}(10)$ & - & - & - & $132.87(10)$ & - \\
\hline $\mathrm{O}(2)-\mathrm{Pb}(1)-\mathrm{O}(7)$ & - & - & - & 139.11(10) & - \\
\hline $\mathrm{O}(2)-\mathrm{Pb}(1)-\mathrm{O}(8)$ & - & - & - & $81.39(11)$ & - \\
\hline $\mathrm{O}(2)-\mathrm{Pb}(1)-\mathrm{O}(9)$ & - & - & - & $162.30(12)$ & - \\
\hline $\mathrm{O}(2)-\mathrm{Pb}(1)-\mathrm{O}(10)$ & - & - & - & $76.44(10)$ & - \\
\hline $\mathrm{O}(3)-\mathrm{Pb}(1)-\mathrm{O}(7)$ & - & - & - & $82.12(14)$ & - \\
\hline $\mathrm{O}(3)-\mathrm{Pb}(1)-\mathrm{O}(8)$ & - & - & - & $137.13(12)$ & - \\
\hline $\mathrm{O}(3)-\mathrm{Pb}(1)-\mathrm{O}(9)$ & - & - & - & 73.17(13) & - \\
\hline $\mathrm{O}(3)-\mathrm{Pb}(1)-\mathrm{O}(10)$ & - & - & - & $160.67(12)$ & - \\
\hline $\mathrm{O}(4)-\mathrm{Pb}(1)-\mathrm{O}(7)$ & - & - & - & $161.35(10)$ & - \\
\hline $\mathrm{O}(4)-\mathrm{Pb}(1)-\mathrm{O}(8)$ & - & - & - & $124.58(11)$ & - \\
\hline $\mathrm{O}(4)-\mathrm{Pb}(1)-\mathrm{O}(9)$ & - & - & - & $102.77(13)$ & - \\
\hline $\mathrm{O}(4)-\mathrm{Pb}(1)-\mathrm{O}(10)$ & - & - & - & $71.14(11)$ & - \\
\hline $\mathrm{O}(7)-\mathrm{Pb}(1)-\mathrm{O}(8)$ & - & - & - & $67.57(11)$ & - \\
\hline $\mathrm{O}(7)-\mathrm{Pb}(1)-\mathrm{O}(9)$ & - & - & - & $58.58(12)$ & - \\
\hline
\end{tabular}




\begin{tabular}{|c|c|c|c|c|c|}
\hline $\mathrm{O}(7)-\mathrm{Pb}(1)-\mathrm{O}(10)$ & - & - & - & $108.88(11)$ & - \\
\hline $\mathrm{O}(8)-\mathrm{Pb}(1)-\mathrm{O}(9)$ & - & - & - & $111.57(12)$ & - \\
\hline $\mathrm{O}(8)-\mathrm{Pb}(1)-\mathrm{O}(10)$ & - & - & - & $62.01(10)$ & - \\
\hline $\mathrm{O}(9)-\mathrm{Pb}(1)-\mathrm{O}(10)$ & - & - & - & $98.55(11)$ & - \\
\hline $\mathrm{O}(7)-\mathrm{Ni}(2)-\mathrm{O}(8)$ & - & - & - & $83.09(13)$ & - \\
\hline $\mathrm{O}(7)-\mathrm{Ni}(2)-\mathrm{O}(11)$ & - & - & - & $85.46(14)$ & - \\
\hline $\mathrm{O}(7)-\mathrm{Ni}(2)-\mathrm{O}(12)$ & - & - & - & $91.24(12)$ & - \\
\hline $\mathrm{O}(7)-\mathrm{Ni}(2)-\mathrm{N}(3)$ & - & - & - & $91.56(15)$ & - \\
\hline $\mathrm{O}(7)-\mathrm{Ni}(2)-\mathrm{N}(4)$ & - & - & - & $173.00(14)$ & - \\
\hline $\mathrm{O}(8)-\mathrm{Ni}(2)-\mathrm{O}(11)$ & - & - & - & $86.60(13)$ & - \\
\hline $\mathrm{O}(8)-\mathrm{Ni}(2)-\mathrm{O}(12)$ & - & - & - & $96.23(12)$ & - \\
\hline $\mathrm{O}(8)-\mathrm{Ni}(2)-\mathrm{N}(3)$ & - & - & - & $174.02(15)$ & - \\
\hline $\mathrm{O}(8)-\mathrm{Ni}(2)-\mathrm{N}(4)$ & - & - & - & $91.59(13)$ & - \\
\hline $\mathrm{O}(11)-\mathrm{Ni}(2)-\mathrm{O}(12)$ & - & - & - & $175.38(14)$ & - \\
\hline $\mathrm{O}(12)-\mathrm{Ni}(2)-\mathrm{N}(3)$ & - & - & - & $86.53(15)$ & - \\
\hline $\mathrm{O}(12)-\mathrm{Ni}(2)-\mathrm{N}(4)$ & - & - & - & $84.81(14)$ & - \\
\hline$N(3)-N i(2)-N(4)$ & - & - & - & $93.96(15)$ & - \\
\hline $\mathrm{O}(11)-\mathrm{Ni}(2)-\mathrm{N}(3)$ & - & - & - & $90.32(15)$ & - \\
\hline $\mathrm{O}(11)-\mathrm{Ni}(2)-\mathrm{N}(4)$ & - & - & - & $98.80(16)$ & - \\
\hline $\mathrm{O}(1)-\mathrm{Pb}(1)-\mathrm{O}(1)^{*}$ & - & - & - & - & $79.47(12)$ \\
\hline $\mathrm{O}(1)-\mathrm{Pb}(1)-\mathrm{O}(2)^{*}$ & - & - & - & - & $88.42(12)$ \\
\hline $\mathrm{O}(1)-\mathrm{Pb}(1)-\mathrm{O}(3)^{*}$ & - & - & - & - & $125.16(14)$ \\
\hline $\mathrm{O}(1)-\mathrm{Pb}(1)-\mathrm{O}(4)^{*}$ & - & - & - & - & $137.35(14)$ \\
\hline $\mathrm{O}(2)-\mathrm{Pb}(1)-\mathrm{O}(2)^{*}$ & - & - & - & - & $149.49(12)$ \\
\hline $\mathrm{O}(2)-\mathrm{Pb}(1)-\mathrm{O}(3)^{*}$ & - & - & - & - & $74.94(14)$ \\
\hline $\mathrm{O}(2)-\mathrm{Pb}(1)-\mathrm{O}(4)^{*}$ & - & - & - & - & $151.03(13)$ \\
\hline $\mathrm{O}(3)-\mathrm{Pb}(1)-\mathrm{O}(3)^{*}$ & - & - & - & - & $173.98(15)$ \\
\hline $\mathrm{O}(3)-\mathrm{Pb}(1)-\mathrm{O}(4)^{*}$ & - & - & - & - & $83.60(15)$ \\
\hline
\end{tabular}




$$
\begin{array}{lllll}
\mathrm{O}(4)-\mathrm{Pb}(1)-\mathrm{O}(4)^{*} & - & - & - & -
\end{array}
$$

\section{References}

(1) G.M. Sheldrick, Crystal structure refinement with SHELXL, Acta Crystallogr., Sect., 2015, C 71, 3-8.

(2) Sheldrick, G. M. SADABS, V2014/5, Software for Empirical Absorption Correction, University of Göttingen, Institute fur Anorganische Chemieder Universitat, Gottingen, Germany, 19992003.

(3) Spackman, M. A.; Jayatilaka, D. Hirshfeld surface analysis. CrystEngComm. 2009, 11, 19-32.

(4) Clausen, H. F.; Chevallier, M. S.; Spackman, M. A.; Iversen, B. B. Three new co-crystals of hydroquinone: crystal structures and Hirshfeld surface analysis of intermolecular interactions. New J. Chem. 2010, 34, 193-199.

(5) Wolff, S. K.; Grimwood, D. J.; McKinnon, J. J.; Jayatilaka, D.; Spackman, M. A. Crystal Explorer 2.0, University of Western Australia, Perth, Australia, 2007, http://hirshfeld surfacenet.blogspot.com.

(6) TURBOMOLE V7.0 2015, a development of University of Karlsruhe and Forschungszentrum Karlsruhe GmbH, 1989-2007, TURBOMOLE GmbH

(7) Grimme, S.; Antony, J.; Ehrlich, S.; Krieg, H. A consistent and accurate ab initio parametrization of density functional dispersion correction (DFT-D) for the 94 elements H-Pu. J. Chem. Phys. 2010, 132, 154104-154109. 
(8) Boys, S. F.; Bernardi, F.; The calculation of small molecular interactions by the differences of separate total energies. Some procedures with reduced errors. Mol. Phys. 1970, 19, 553-566.

(9) Contreras-García, J.; Johnson, E. R.; Keinan, S.; Chaudret, R.; Piquemal, J.-P.; Beratan, D. N.; Yang, W. NCIPLOT: A Program for Plotting Noncovalent Interaction Regions. J. Chem. Theory Comput. 2011, 7, 625-632.

(10) Johnson, E. R.; Keinan, S.; Mori-Sanchez, P.; Contreras-Garcia, J.; Cohen, A. J.; Yang, W. Revealing Noncovalent Interactions. J. Am. Chem. Soc. 2010, 132, 6498-6506.

(11) Gaussian 09, Revision C.02, M. J. Frisch, G. W. Trucks, H. B. Schlegel, G. E. Scuseria, M. A. Robb, J. R. Cheeseman, G. Scalmani, V. Barone, G. A. Petersson, H. Nakatsuji, X. Li, M. Caricato, A. Marenich, J. Bloino, B. G. Janesko, R. Gomperts, B. Mennucci, H. P. Hratchian, J. V. Ortiz, A. F. Izmaylov, J. L. Sonnenberg, D. Williams-Young, F. Ding, F. Lipparini, F. Egidi, J. Goings, B. Peng, A. Petrone, T. Henderson, D. Ranasinghe, V. G. Zakrzewski, J. Gao, N. Rega, G. Zheng, W. Liang, M. Hada, M. Ehara, K. Toyota, R. Fukuda, J. Hasegawa, M. Ishida, T. Nakajima, Y. Honda, O. Kitao, H. Nakai, T. Vreven, K. Throssell, J. A. Montgomery, Jr., J. E. Peralta, F. Ogliaro, M. Bearpark, J. J. Heyd, E. Brothers, K. N. Kudin, V. N. Staroverov, T. Keith, R. Kobayashi, J. Normand, K. Raghavachari, A. Rendell, J. C. Burant, S. S. Iyengar, J. Tomasi, M. Cossi, J.M. Millam, M. Klene, C. Adamo, R. Cammi, J. W. Ochterski, R. L. Martin, K. Morokuma, O. Farkas, J. B. Foresman, D. J. Fox, Gaussian, Inc., Wallingford CT, 2016.

(12) Hirshfeld, F. L. Bonded-Atom Fragments for Describing Molecular Charge Densities. Theor. Chim. Acta. 1977, 44, 129-138.

(13) Mckinnon, J. J.; Jayatilaka, D.; Spackman, M. A. Towards quantitative analysis of intermolecular interactions with Hirshfeld surfaces. ChemCommun. 2007, 3814-3816. 
(14) McKinnon, J. J.; Spackman, M. A.; Mitchell, A. S. Novel tools for visualizing and exploring intermolecular interactions in molecular crystals. ActaCryst. B. 2004, 60, 627-668.

(15) Spackman, M. A.; McKinnon, J. J. Fingerprinting intermolecular interactions in molecular crystals. CrystEngComm. 2002, 4, 378-392. 